LITERATURE REVIEW : PENERAPAN TEKNIK RELAKSASI NAFAS DALAM TERHADAP PENURUNAN NYERI PADA PASIEN

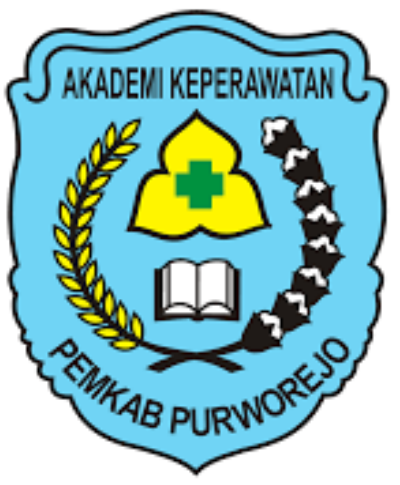

Oleh :

DWI UTAMI

18065 


\title{
LITERATURE REVIEW : PENERAPAN TEKNIK RELAKSASI NAFAS DALAM TERHADAP PENURUNAN NYERI PADA PASIEN
}

\author{
NASKAH PUBLIKASI
}

Diajukan Sebagai Salah Satu Syarat

Mendapatkan Gelar Ahli Madya Keperawatan (A.Md. Kep)

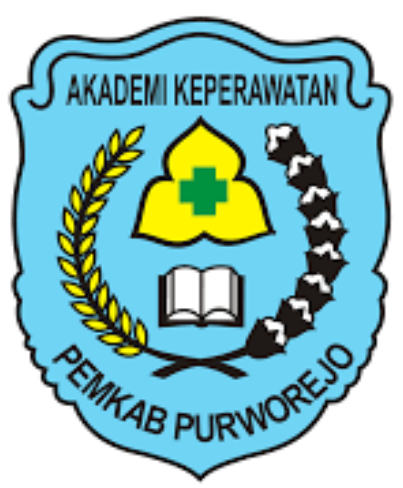

Oleh :

DWI UTAMI

18065 


\section{LEMBAR PENGESAHAN}

Naskah Publikasi dengan judul “LITERATURE REVIEW : PENERAPAN TEKNIK RELAKSASI NAFAS DALAM TERHADAP PENURUNAN NYERI PADA PASIEN" oleh Dwi Utami (18065) telah disetujui dan diujikan didepan Dewan Penguji pada tanggal 26 Agustus 2021

Dewan Penguji

Penguji I

Penguji II

Penguji III

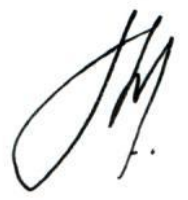

Bayu Seto R.A, S.Kep.Ns.,M.Kep

NIDN : 0625118907

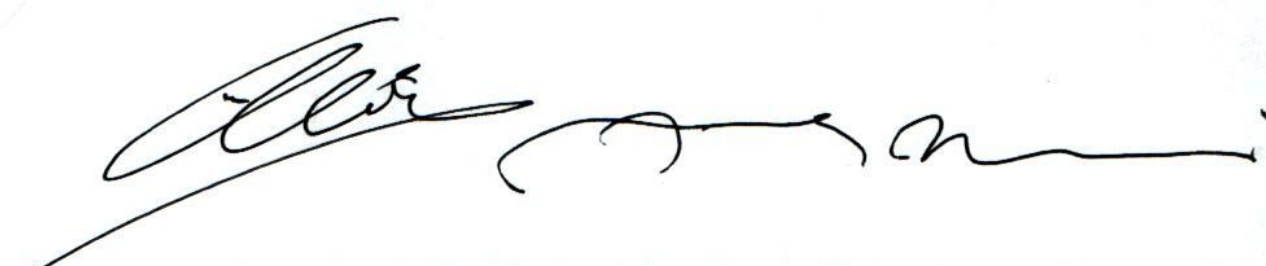

Wahyu Widodo, S.Kp.Ns.,M.Kep

NIDN : 0609087301
Ahmad Muzaki, S.Kep.Ns.,M.Kep

NIDN : 0622038902

Mengetahui,

Akademi Keperawatan Pemkab Purworejo

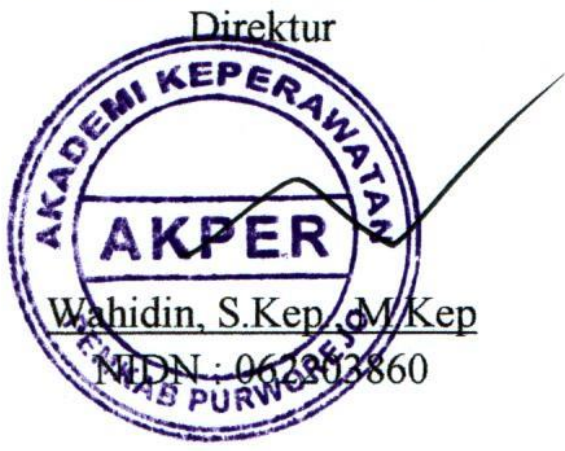




\title{
LITERATURE REVIEW : PENERAPAN TEKNIK RELAKSASI NAFAS DALAM TERHADAP PENURUNAN NYERI PADA PASIEN
}

\author{
Dwi Utami ${ }^{1}$, Ahmad Muzaki $^{2}$, Wahyu Widodo ${ }^{3}$ \\ Mahasiswa Akademi Keperawatan Pemkab Purworejo ${ }^{1}$ \\ Dosen Akademi Keperawatan Pemkab Purworejo ${ }^{2}$ \\ Dosen Akademi Keperawatan Pemkab Purworejo ${ }^{3}$ \\ Purworejo, (0275)3140576 \\ Email : dwitamtamtem@gmail.com
}

\begin{abstract}
ABSTRAK
Latar Belakang : Perasaan yang bersifat tidak menyenangkan disebut nyeri. Berhubungan dengan rusaknya jaringan yang muncul secara mendadak serta berskala ringan sampai berat selama 3 bulan kurang. Nafas dalam dapat dilakukan sebagai tindakan menurunkan nyeri pada saat nyeri timbul. Nafas lembut serta mengeluarkan dengan pelan. Tujuan : Mengetahui pengaruh relaksasi nafas dalam sebagai tindakan mengatasi masalah keperawatan nyeri pada klien. Metode : Penulis menggunakan metode Literature Review dengan cara menguraikan teori, temuan serta bahan penelitian dari beberapa peneliti yang digunakan untuk landasan dalam melakukan studi literatur. Pencarian artikel dilakukan dengan Google Scholar yang dipublikasikan sejak tahun 2016 sampai dengan 2020 yang diakses full text dalam format pdf berbahasa Indonesia dengan kata kunci"nafas dalam+"nyeri"+"IGD", "nyeri"+"nafas dalam"+"gawat darurat" dan "teknik relaksasi nafas dalam"+"IGD". Hasil : Berdasarkan kelima artikel yang penulis review menunjukkan bahwa 3 artikel diantarnya menyatakan bahwa hasil pemberian relaksasi nafas dalam efektif untuk menurunkan nyeri dan 2 artikel menyatakan hasil bahwa relaksasi nafas dalam tidak memiliki pengaruh terhadap penurunan nyeri setelah dilakukan relaksasi nafas dalam. Kesimpulan : Teknik relaksasi nafas dalam dapat menurunkan nyeri pada pasien.
\end{abstract}

Kata Kunci : Nyeri, Nafas Dalam, IGD

\section{ABSTRACT}

Background : Pain is a subjective unpleasant feeling condition. Sensory or emotional experience associated with tissue damage of sudden onset and of mild to severe intensity lasting less than 3 month. Deep breathing relaxation techniques can be used to reduce the patient's pain when pain occurs. Breathe gentely (hold inspiration maximally) and exhale slowly. Objective : To determine the effect of deep breathing relaxation to overcome pain nursing problems in clients. Methods: This type of research uses the Literature Review method by outlining theories, findings and research materials from several researchers which are used as the 
basis for conducting literature studies. Article searches were carried out using Google Scholar publised from 2016-2020 which were accessed in full text in Indonesian language pdf format with the keywords "deep breath"+"pain"+"IGD", "pain"+"deep breath"+"emergency" and "deep breathing relaxation technique"+"IGD. Results: based on the five articles reviewed by the authors, it showed that the majority of patients experienced a decrease in pain after deep breathing relaxation and deep breating relaxation techniques had an effect on reducing pain intensity. Conclusion: Deep breathing relaxation techniques can reduce pain in patients.

Keywords : Pain, Deep Breath, IGD

\section{Pendahuluan}

Nyeri berhubungan dengan rusaknya jaringan aktual maupun fungsional, selama 3 bulan kurang dengan onset mendadak (Desiartama, 2017). Kasus nyeri kronis di dunia sekitar $20 \%$ dari popuasi didunia. Jumlah nyeri akut $42 \%$ di Inggris, kejadian pada pria $17 \%$ serta wanita 25\% (Hartanti, 2016). Berdasarkan data WHO tahun 2015, jumlah pasien pembedahan meningkat setiap tahun, 2011 sebanyak 140 juta klien atau sekitar 1,9\% diseluruh dunia, 2012 meningkat dengan jumlah 148 juta pasien atau 2,1\%.

Indonesia mengalami kasus nyeri sekitar 12,7 juta atau sekitar $5 \%$ populasi indonesia, kejadian nyeri gastritis di indonesia sebanyak 23,5-31,3\%, nyeri fraktur di indonesia sebanyak 40\% (WHO, 2015). Diperkirakan $40 \%$ penduduk
Jawa Tengah kasus nyeri mencapai 18,2\% untuk laki laki sedangkan perempuan 13,6\% (Hartanti, 2016).Relaksasi yaitu tindakan megurangi nyeri dengan merelaksasi otot, teknik ini berguna untuk memberikan penurunan skala nyeri (Suhartini, 2013). Teknik ini berguna untuk menekan nyeri di thalamus lalu ke kortek cerebri sebagai pusat nyeri. Saat melakukan teknik nafas dalam harus di suasanya yang nyaman, tenang serta rileks agar tujuan dari teknik ini tercapai.

\section{Metode Penelitian}

Metode penelitian yang
digunakan pada penelitian adalah
literatur review, yaitu mengumpulkan
dan menganalisis artikel-artikel
penelitian mengenai penerapan teknik relaksasi nafas dalam. Penelusuran artikel dilakukan dengan pendekatan kata (data base) google scholar 
dengan menggunakan kata kunci

Dalam mereview literatur

seperti "teknik relaksasi nafas menggunakan beberapa cara dalam" + "fraktur" + "IGD", diantaranya: mencari kesamaan "nyeri"+"nafas dalam" +"gawat (Similarity), ketidaksamaan (Contrast), darurat", "nafas dalam"+ "nyeri" memberi pandangan (Critize), +'IGD", artikel yang dipublikasikan sejak tahun 2016-2020 yang membandingkan (Compare), dan meringkas (Sumarize).

dapatdiakses full teks dalam format PDF dan berbahasa indonesia.

\section{Hasil}

Hasil analisis literatur diambil

Analisa data dilakukan dengan cara mendiskusikan dan meringks literatur kemudian membandingkan beberapa literatur dan selanjutnya dituangkan dalam pembahasan.

ma artikel yang sudah dilakukan pemilihan topik, penentuan keyword dan selanjutnya dianalisis melalui proses persamaan dan perbedaan yang disajikan dalam tabel 1.

Tabel 1. Ringkasan Dari Literatur Tentang Penerapan Teknik Relaksasi Nafas Dalam Terhadap Penurunan Nyeri Pada Pasien.

\begin{tabular}{|c|c|c|c|c|c|}
\hline No & $\begin{array}{l}\text { Nama } \\
\text { Penulis }\end{array}$ & Judul & $\begin{array}{l}\text { Metode } \\
\text { Penelitian }\end{array}$ & $\begin{array}{l}\text { Subjek } \\
\text { Penelitian }\end{array}$ & Hasil \\
\hline 1. & $\begin{array}{l}\text { Mochamad } \\
\text { Tri } \\
\text { Hastomo, } \\
2018\end{array}$ & $\begin{array}{l}\text { Teknik } \\
\text { Relaksasi } \\
\text { Nafas Dalam } \\
\text { Terhadap } \\
\text { Skala Nyeri } \\
\text { Pada Saat } \\
\text { Pemasangan } \\
\text { Infus Di } \\
\text { Instalasi } \\
\text { Gawat Darurat }\end{array}$ & $\begin{array}{l}\text { Metode } \\
\text { penelitian } \\
\text { kuantitatif } \\
\text { dengan desain } \\
\text { penelitian pre } \\
\text { experimental } \\
\text { design dengan } \\
\text { one shot case } \\
\text { study }\end{array}$ & $\begin{array}{l}\text { Sampel yang } \\
\text { digunakan } \\
\text { berjumlah } 30 \\
\text { sampel dengan } \\
\text { teknik } \\
\text { purposive } \\
\text { sampling }\end{array}$ & $\begin{array}{l}\text { Didapatkan hasil bahwa } \\
\text { pengaruh tidak ada antara } \\
\text { skala nyeri dan nafas } \\
\text { dalam saat pemasangan } \\
\text { infus. Dai uji statistik } \\
\text { didapatkan nilair } p \text { value } \\
=0,54 \text { berarti nilai } p>0,05\end{array}$ \\
\hline 2. & $\begin{array}{l}\text { Irfan Irianto, } \\
2019\end{array}$ & $\begin{array}{l}\text { Hubungan } \\
\text { Penanganan } \\
\text { Awal Gastritis } \\
\text { Dengan Skala } \\
\text { Nyeri Pasien } \\
\text { UGD Rumah } \\
\text { Sakit GNIM } \\
\text { Bethesda } \\
\text { Termohon }\end{array}$ & $\begin{array}{l}\text { Metode } \\
\text { penelitian } \\
\text { kuantitatif } \\
\text { dengan desain } \\
\text { penelitian } \\
\text { studi korelasi } \\
\text { dengan } \\
\text { pendekatan } \\
\text { cross sectional }\end{array}$ & $\begin{array}{lr}\text { Sampel yang } \\
\text { digunakan } \\
\text { berjumlah } 52 \\
\text { sampel dengan } \\
\text { teknik non } \\
\text { random r } \\
\text { sampling }\end{array}$ & $\begin{array}{l}\text { Didapatkan hasil bahwa } \\
\text { penatalaksanaan awal } \\
\text { gastritis dengan nafas } \\
\text { dalam tidak memiliki hasil } \\
\text { yang signifikan. } \\
\text { Digunakan uji spearman } \\
\text { dalam peneitian ini } \\
\text { dengan nilai p } 0,066 ; \alpha \\
0,05\end{array}$ \\
\hline
\end{tabular}




\begin{tabular}{|c|c|c|c|c|c|}
\hline 3. & $\begin{array}{l}\text { Lela } \\
2018\end{array}$ & $\begin{array}{l}\text { Pengaruh } \\
\text { Teknik } \\
\text { Relaksasi } \\
\text { Nafas Dalam } \\
\text { Terhadap } \\
\text { Penurunan } \\
\text { Nyeri Pada } \\
\text { Pasien Fraktur }\end{array}$ & $\begin{array}{l}\text { Metode } \\
\text { penelitian } \\
\text { kuantitatif } \\
\text { dengan desain } \\
\text { penelitian pra- } \\
\text { eksperimental } \\
\text { dengan } \\
\text { rancangan one } \\
\text { group pretest } \\
\text { posttest }\end{array}$ & $\begin{array}{l}\text { Sampel yang } \\
\text { digunakan } \\
\text { berjumlah } 30 \\
\text { sampel dengan } \\
\text { teknik } \\
\text { purposive } \\
\text { sampling }\end{array}$ & $\begin{array}{l}\text { Diperoleh hasil adanya } \\
\text { pengaruh nafas dalam } \\
\text { terhadap penurunan nyeri } \\
\text { frktur. } \\
\text { menggunakan uji wilocon } \\
\text { diperoleh hasil ( } p- \\
\text { value=0,001) dengan } \\
\text { makna terdapat pengaruh } \\
\text { relaksai nafas dalam } \\
\text { terhadap penurunan nyeri. }\end{array}$ \\
\hline 4. & $\begin{array}{l}\text { Wahyu } \\
\text { Widodo, } \\
\text { Neli Qoniah, } \\
2020\end{array}$ & $\begin{array}{l}\text { Penerapan } \\
\text { Teknik } \\
\text { Relaksasi } \\
\text { Nafas Dalam } \\
\text { Untuk } \\
\text { Menurunkan } \\
\text { Intensitas } \\
\text { Nyeri Pada } \\
\text { Pasien } \\
\text { Appendictis Di } \\
\text { RSUD Wates }\end{array}$ & $\begin{array}{l}\text { Metode } \\
\text { penelitian } \\
\text { kualitatif } \\
\text { dengan desain } \\
\text { penelitian } \\
\text { deskriptif } \\
\text { dalam bentuk } \\
\text { studi kasus }\end{array}$ & $\begin{array}{l}\text { Sampel yang } \\
\text { digunakan } \\
\text { berjumlah } 2 \\
\text { sampel }\end{array}$ & $\begin{array}{l}\text { Didapatkan hasil bahwa } \\
\text { terdapat perbedaan saat } \\
\text { sebelum operasi, sebelum } \\
\text { dan setelah diberikan } \\
\text { relaksasi nafas dalam. }\end{array}$ \\
\hline 5. & $\begin{array}{l}\text { Ibnu Habib, } \\
2021\end{array}$ & $\begin{array}{l}\text { Studi } \\
\text { Komparatif } \\
\text { Skala Nyeri } \\
\text { Saat } \\
\text { Pemasangan } \\
\text { Infus Ada } \\
\text { Anak Yang } \\
\text { Diberikan } \\
\text { Teknik } \\
\text { Distraksi } \\
\text { Audio Visual } \\
\text { Menonton } \\
\text { Animasi Dan } \\
\text { Kartun Dan } \\
\text { Teknik } \\
\text { Relaksasi } \\
\text { Nafas Dalam }\end{array}$ & $\begin{array}{l}\text { Metode } \\
\text { penelitian } \\
\text { kuantitatifdeng } \\
\text { an desain } \\
\text { penelitian } \\
\text { studi } \\
\text { komparatif pre } \\
\text { test one group } \\
\text { design }\end{array}$ & $\begin{array}{l}\text { Sampel } \\
\text { yangdigunakan } \\
\text { berjumlah } 30 \\
\text { sampel dengan } \\
\text { teknikpurposiv } \\
\text { e sampling }\end{array}$ & $\begin{array}{l}\text { Didapatkan hasil yang } \\
\text { menunjukkan terdapat } \\
\text { perbedaan antara terapi } \\
\text { distraksi animasi kartun } \\
\text { dengan nafas dalam saat } \\
\text { memasang infus pada } \\
\text { anak di ruang UGD RSI } \\
\text { Siti Aisyah. Disimpulkan } \\
\text { bahwa distraksi menonton } \\
\text { animasi kartun lebih } \\
\text { efektif untuk penurunan } \\
\text { skala nyeri saat tindakan } \\
\text { infasif dari pada teknik } \\
\text { nafas dalam. Penelitian ini } \\
\text { menggunakan uji statistik } \\
\text { independent test } p \\
=\text { value } 0,000 \text { yak } \\
\text { maknanya ada perbedaan. }\end{array}$ \\
\hline
\end{tabular}

\section{Pembahasan}

Dari kelima artikel yang telah dilakukan review diatas, terdapat perbedaan pada masing-masing penelitian. Perbedaan dilihat dari kelima jurnal memiliki perbedaan dalam hal desain penelitian pada penelitian Mochamad Tri Hastono (2018) menggunakan metode preexperimental design dengan one shot casestudy. Metode penelitian preexperimental menurut Sugiyono 
(2014) adalah sebuah rancangan yang diberikan hanya pada suatu grub tertentu. Irfan Irianto (2019) menggunakan studi korelasi dengan pendekatancross sectional. Lela Aini (2018) menggunakan pra-eksperimental dengan rancanganpre test-post test. Wahyu Widodo, Neli Qoniah, (2020) menggunakan design studi kasus, Ibnu Habib (2021) menggunakan design pre test one grup.

Teknik pengambilan sampel yang dilakukan oleh Mochamad Tri Hastomo (2018), Lela Aini (2018), Ibnu Habib (2021) yaitu menggunakan purposive sampling. Pengambilan sampel yang dilakukan oleh Irfan Irianto (2019) menggunakan teknik non random sampling.

Jumlah sampel yang sama pada penelitian Mochamad Tri Hastono (2018), Lela Aini (2018), Ibnu Habib (2021) yaitu sama-sama menggunakan 30 reponden. Selanjutnya persamaan jurnal dilihat dari hasil dari penelitian terkait teknik relaksasi nafas dalam pada penelitian Irfan Irianto (2019), Lela Aini (2018), Wahyu Widodo, Neli Qoniah, (2020) yaitu menunjukkan bahwa ada keefektifan menurunkan nyeri pada pasien.

Selanjutnya persamaan jurnal dilihat dari hasil dari penelitian terkait teknik relaksasi nafas dalam pada penelitian Mochamad Tri Hastono (2018), Ibnu Habib (2021) yaitu menunjukkan bahwa pengaruhnya tidak ada saat dilakukan nafas dalam untuk penurunan nyeri. Persamaan selanjutnya yaitu dilihat dari penggunaan instrumen yaitu pada Lela Aini (2018), Irfan Irianto (2019) dan Wahyu Widodo, Neli Qoniah, (2020) sama-sama menggunakan Numeric Rating Scale dalam pengukuran skala nyeri. Pandangan penulis tentang artikel yaitu sesuai dengan kosep yang dinyatakan oleh beberapa peneliti terkait dengan penerapan nafas dalam untuk penurunan nyeri.

Instrumen digunakan Mochamad Tri Hastomo (2018) yaitu dengan obsevasi chek list, memberikan tanda centang apabila menunjukkan gejala pada sasaran. Irfan Irianto yaitu pengumpulan data menggunakan alat ukur kuisioner yang telah baku dan tervalidasi, dengan hasil perhitungan 
skala koefisien reprodusibilitas sebesar 0,98 dan skala koefisien skalabilitas 0,97 . Penelitian Wahyu Widodo dengan SOP yang ada di Rumah Sakit Wates dengan pengukuran nyeri menggunakan Numerical Rating Scale.

Perbedaan selanjutnya dilihat dari pengukuran skala nyeri yang digunakan dalam penelitian Mochamad Tri Hastono (2018) menggunakan visual analog dalam mengukur skala nyeri, Ibnu Habib (2021) menggunakan wong beker pain rating scale. Perbandingan dari setiap penelitian terdapat pada metode penelitian yang digunakan pada masingmasing peneliti. Berdasarkan kelima artikel diatas bahwa teknik relaksasi nafas dalam dapat digunakan untuk mengatasi nyeri secara nonfarmakologis.

Hal didukung penelitian Hartanti (2016) yang berjudul relaksasi terapi nafas dalam penurunan nyeri pada klien dengan hipertensi menyatakan adanya penurunan skala nyeri 5 menjadi 3 setelakah diakukan nafas dalam.

\section{Kesimpulan}

Kelima artikel memiliki kesamaan dalam teknik pengambilan sampel, hasil penelitian menunjukkkan adanya penurunan nyeri setelah dilakukan relaksasi nafas dalam. Sedangkan perbedaan terdapat pada desain penelitian, instrumen penelitian yang digunakan pada penelitian.

Dari kelima artikel yang telah dilakukan review, penulis dapat menyimpulkan bahwa. Teknik relaksasi nafas dalam efektif dalam menurunkan nyeri dan dapat diterapkan sebagai tindakan nonfarmakologis untuk menurunkan nyeri pada pasien.

\section{Ucapan Terimakasih}

Penulis mengucapkan terimakasih kepada direktur akademi keperawatan pemkab purworejo dan dosen pembimbing yang telah memberikan bimbingan dalam penyelesaian publikasi ini. Serta tidak lupa kepada kedua orang tua, kakakku dan teman-teman semua yang telah memberikan doa serta support untuk menyelesaikan publikasi ini. 


\section{Daftar pustaka}

Desiartama, A, dan I G N W, Aryana. (2017). Gambaran Karakteristik Pasien Fraktur Femur Akibat Kecelakaan Lalulintas Pada Orang Dewasa Di Rumah Sakit Umum Pusat Sanglah Denpasar Tahun 2013. E-Journal Medika. 06 (05) : 1-4

Hartanti, R Desnanda P. (2016). Terapi Relaksasi Nafas Dalam Menurunkan Nyeri Pada Pasien Hipertensi. Jurnal Keperawatan Kesehatan (JIK). Vol IX, No 1, Maret 2016. https://media.neliti.com./

Diakses 10 Januari 2019

Hastomo, M. T., \& Suryadi, B. (2017). Teknik Relaksasi Nafas Dalam Terhadap Skala Nyeri Pada Saat Pemasangan Infus di Instalasi Gawat Darurat. Jurnal Ilmiah Ilmu Keperawatan Indonesia, 8(2), 436-442

Lela, A., \& Reza, R. (2018). Pengaruh Teknik Relaksasi Nafas Dalam terhadap Penurunan Nyeri pada Pasien Fraktur. Jurnal Kesehatan, 9(2), 262-266

Mustofa, I. H., Verawati, M., \& Sari, R. M. (2021). Studi Komparatif Skala Nyeri Saat Pemasangan Infus Pada Anak Yang Diberikan Teknik Distraksi Audio Visual Menonton Animasi Kartun Dan Teknik Relaksasi Tarik Nafas Dalam Di Rsi Siti Aisyah Kota Madiun. Health Sciences Journal, 5(1), 1-13.
Purwati. (2010). Penurunan Tingkat Nyeri Anak Prasekolah Yang Mengalami Penusukan Intravena Untuk Pemasangan Infus Melalui Terapi Musik. Jurnal Keperawatan Indonesia 13, 50-51

Rizky, I. I., Kepel, B. J., \& Killing, M. (2019). Hubungan Penanganan Awal Gastritis Dengan Skala Nyeri Pasien Ugd Rumah Sakit Gmim Bethesda Tomohon. Jurnal Keperawatan, $7(1)$.

Suhartini dkk. (2013). Pengaruh Teknik Relaksasi Terhadap Intensitas Nyeri Pada Pasien Post Operasi Fraktur Diruang Iriana A BLU RSUP Prof DR.R.D Kandou Manado. Ejournal.unsrat.ac.id/index.php/ jkp/article/view/2243.

Wahyu Widodo, Neli Qoniah. (2020). Penerapan Teknik Relaksasi Nafas Dalam Menurunkan Intensitas Nyeri Pada Pasien Appendicitis Di Rsud Wates. Nursing Science Journal (NSJ), 1(1), 25-28. https://doi.org/10.53510/nsj.v1i 1.17

WHO. World Health Statistic Report. (2014). Geneva: world Health Organization; 